\title{
Solar Integrated Energy Efficient Systems for Waste Heat Recovery of Power Generation Industry Using Different Eco-Friendly Energy Materials
}

\author{
${ }^{1}$ R. S. Mishra, ${ }^{2 *}$ Kaushalendra Kr Dubey \\ *Kaushalendra Kr.Dubey \\ e-mail-dubey.kaushalendra@gmail.com \\ School of Mechanical Enginering,Galgotias University \\ Gautam Budha Nagar,UP State,India
}

\begin{abstract}
-
The two major issues are being disused in these days globally, $\mathrm{CO}_{2}$ concentration in atmosphere on one hand and energy crisis on other hand. All promising savings of reducing $\mathrm{CO}_{2}$ generation, fossil fuels depletion, control in energy prices increments, achievable by adaptation of eco-friendly energy efficient material based technology. The un-arrested heat discharge from captive power plants, cement production, steel industry, Oil-refineries, like energy intensive industries have tremendous potential for multiple energy generation (heating-power \& cooling) for further industrial process with dumped heat recovery. This paper explores eco-friendly material R134a and activated carbon-methanol based organic Rankine model and solar integrated vapor adsorption cooling system for waste heat utilization of condenser unit of steam power plant. The results of proposed model analysis is to explain the environmental parameters of used material, effect of operating parameters and cooling-power output.
\end{abstract}

\section{Keywords}

Global Warming Potential, Ozone Déplétion Potential, Solar Integrated Waste Heat Recovery System.

\section{Introduction}

The uncovered heat from power plants and heavy industry is dumped into atmosphere and it causes of severe impact on atmosphere in terms of green house effect. The US Dept of Energy reported that the cement/ captive power plants have, nearly $35 \%$ heat is lost, and this corresponds to around 70 to $75 \mathrm{MW}$ of thermal energy. EPA estimated that the $65 \%$ of world $\mathrm{CO}_{2}$ emission is recorded from green house gas emission from fissile fuel burning during intensive industrial process [1,2]. This un-used or waste heat have tremendous potential to generate heating-power and cooling generation for industrial process by using eco-friendly material based novel thermodynamic system like, organic rankine system (ORC), kalina system for cooling-power generation, vapor absorption and adsorption refrigeration techniques. The employment of solar energy will enhance the system performance. All these systems work as waste heat recovery generator (WHRG). For a 6000 ton per day (tpd) capacity of cement plant can be reduced around 70,000 ton/annum of $\mathrm{CO}_{2}$ by installation of WHRG [1]. The proposed analysis is concern with the condenser heat recovery of reheating-rankine steam power plant by using eco-friendly material based ORC and vapor adsorption cooling system for simultaneously power and cooling generation. Two models have been analyzed in this paper, model 1 (fig-1) integrated with solar ORC and model 2(fig-2) equipped with double bed adsorption refrigeration system. Model 2 has two different adsorber beds, bed1 is connected with condenser outlet of reheating-rankine steam plant and AC-Methanol (Activated Carbon)material pair is used and bed 2 integrated with solar parabolic collector for condenser water 
heating that heated water circulating to bed 2 for generator purpose. The main objective of this analysis to estimate the multiple thermal effect (heating-power and cooling) from available un-covered heat of power plant by using different novel thermal system. The application of R134a and AC-Methanol type material helps to produce required cooling effect at low grade of thermal availability with environmental safety aspect.The numerous researches have been developed and analyzed eco-friendly material based novel thermodynamic model in environmental concern. The selection of a suitable working material depends on its great influence in the design of the process, application, heat source and the temperature level. The used material must have optimum thermodynamic properties at the lowest possible temperatures and pressures, and also satisfy several criteria such as economical, nontoxic, nonflammable, environmentally friendly. An extensive literature review of R134a was chosen as working fluid. This selection has been done on the basis that R134a: is a nontoxic and nonflammable fluid and its Ozone Depletion Potential (ODP) is zero. R134a has a high molecular mass (chemical formula: $\mathrm{CF} 3 \mathrm{CH} 2 \mathrm{~F}, \mathrm{MM}=102 \mathrm{~kg} / \mathrm{kmol}$ ). It has a temperature and critical pressure of $101.1^{\circ} \mathrm{C}$ and 40.6 bar, respectively, R134a based heat recovery ORC of condenser operates at a higher pressure than atmospheric, and therefore air in-leakages do not occur. [3,4-6] Several researchers have investigated the application and performance of ORC with R134a as a working fluid, the efficiency of the ORC using benzene, ammonia, R134a, R113, R11 and R12 was analyzed [7-9] An analysis of a regenerative ORC based on the parametric optimization, using R12, $\mathrm{R} 123$, R134a, and R717 as working fluids superheated at constant pressure was carried out and. results revealed that selection of a regenerative ORC during overheating using R123 as working fluid appears to be a good system for converting low-grade waste heat to power[10]. In a low-temperature solar organic Rankine cycle system was designed and built with R134a as working fluid that works between $35.0^{\circ} \mathrm{C}$ and $75.8^{\circ} \mathrm{C}$ for reverse osmosis desalination in Greece, the results showed a system efficiency of about $7 \%$ and $4 \%$, respectively. Other studies that have analyzed the use of R134a as working fluid in the ORC cycles for reverse osmosis desalination at an experimental level [11-13], and also as a theoretical manner showed a simulation to estimate the increase in the efficiency and the energy available for desalination of an upper ORC coupled with a lower ORC with R134a, obtaining an efficiency for the latter of $4.2 \%$. Other cycles with R134a for applications for geothermal sources are reported also and R134a integrated with internal combustion engine for heat recovery as bottoming cycle [14-23]. The overall screening of all heat recovery fluids R134a was found to be the most suitable in terms of most eco-friendly, non-toxic, high thermal performance for cooling and power generation with optimized system. Another category of energy recovery material for green refrigeration technology is vapor adsorption refrigeration. Activated carbon is a form of carbon that has been processed to make it extremely porous, and it has a large surface area available for adsorption. Methanol and ammonia are the most common refrigerants paired with activated carbon. Activated carbon-methanol is one of the most promising working pairs in practical systems because of its large adsorption quantity and low adsorption heat (about 1800 to $2000 \mathrm{~kJ} \cdot \mathrm{kg}-$ 1[24]. Low adsorption heat is beneficial to the system's performance because the majority of heat consumption in the desorption phase is the adsorption heat. Another advantage of activated carbon-methanol is low desorption temperature (about $100^{\circ} \mathrm{C}$ ), which is within a suitable temperature range for using solar energy as a heat source. Activated carbon-ammonia has almost the same adsorption heat as the activated carbon-methanol working pair.The drawbacks of this working pair are the toxicity and pungent smell of ammonia. Silica gel is a granular, highly porous form of silica made synthetically from sodium silicate. For the silica gel-water working pair, the adsorption heat is about $2500 \mathrm{~kJ} / \mathrm{kg}$ and the desorption temperature could be as low as $50^{\circ} \mathrm{C}$ [24-25].

Model-1 -R134a Based Solar Integrated ORC Waste Heat Recovery System.

Model-2-Activated Carbon based Solar Integrated Vapour Adsorption Cooling System For Condenser Waste Heat Recovery. 

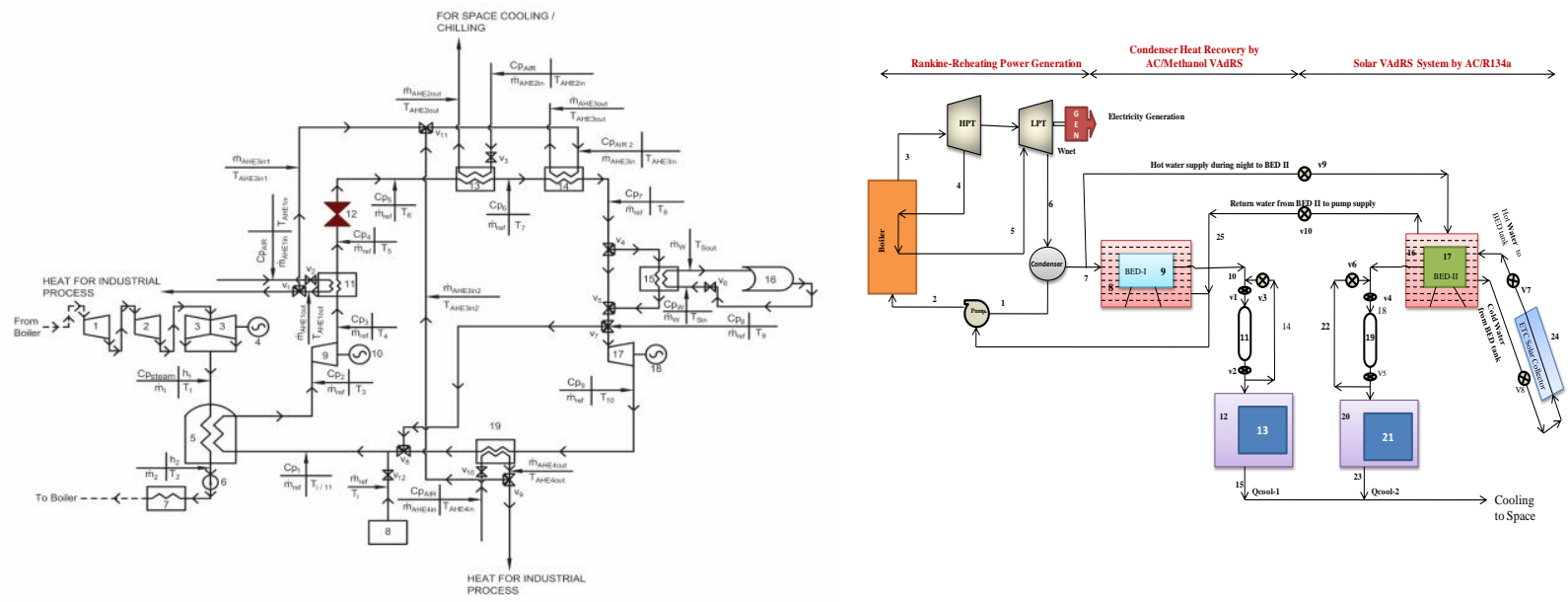

Fig-1, Schematic of R134a Based ORC heat recovery Unit

Fig-2: Solar Integrated Vapor Adsorption System for Condenser Heat Recovery (Model-1)

\section{Results and Discussion}

Increasing the mass flow rate of air in HE2 increases the heat obtained thereby reducing the cooling effect and heating the air more. In operation cycle with solar heater the change in heat obtained and the rise in air temperature for a small increase in mass flow rate of air is much more than that in the operation cycle without solar heater. Fig 3 depicts the efficiency of scroll type expander is in the range of $14 \%$ to $25 \%$ of model1. The expander in case of cycle without solar integration will do more work. In case of solar integration, more heat for industrial process will be obtained.
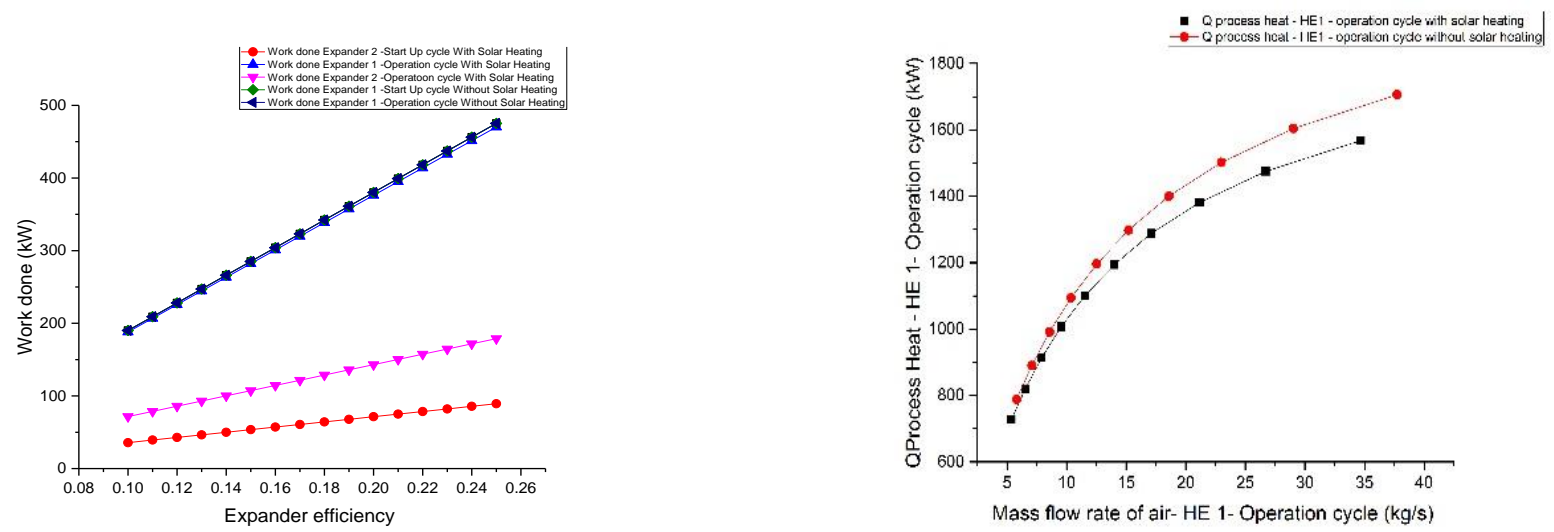

Figure 3: Effect of expander efficiency on work done by expander

Fig 4 explains that when solar heating is not implemented, the heat for process obtained from HE 1 will be more in both cycles than that obtained when solar heating is implemented. Moreover, the gain in the 
heat obtained from HE 1, for process, per unit increase of mass flow rate of air passing through the HE 1, in case of operation cycle, is greater when solar heating is not implemented than when solar heating is implemented. All parametric results are concluded in Table $1 \& 2$ of both model $1 \& 2$.

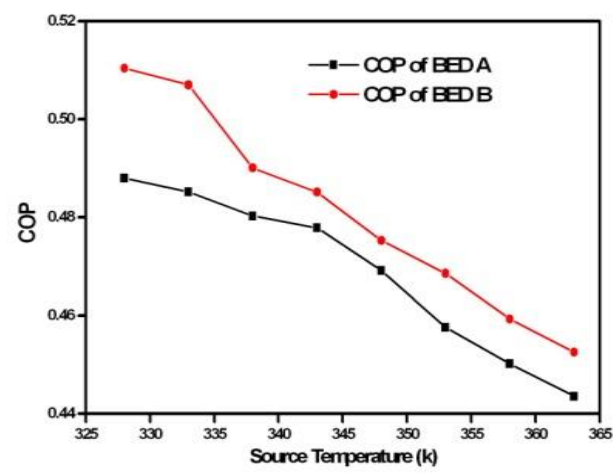

Fig-5 COP Vs Source Temp Of VADRS

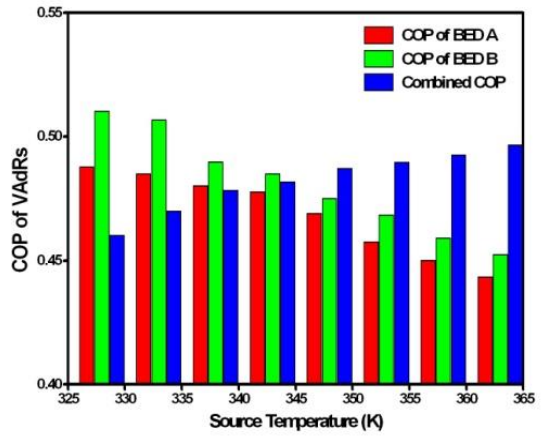

Fig-6-Cpmbined COP Vs Source Temp of VADRS

Table-1-Parametric Results Of ORC Heat Recovery System

\begin{tabular}{|c|c|c|}
\hline Parametric Results & Cycle without solar & Cycle with solar \\
\hline$\eta_{\text {thermal }}$ & $8-15 \%$ & $12-27 \%$ \\
\hline$\eta_{\text {expander }}$ & $10-25 \%$ & $10-25 \%$ \\
\hline Process Heat $\left(\mathrm{Q}_{\text {process heat }}\right)$ & $900-1100 \mathrm{~kW}$ & $1200-1500 \mathrm{~kW}$ \\
\hline Cooling Effect $\left(\mathrm{Q}_{\text {cooling }}\right)$ & $14-19.25 \mathrm{~kW}$ & $35-38.5 \mathrm{~kW}$ \\
\hline Expander work $\left(\mathrm{W}_{\text {expander }}\right)$ & $200-470 \mathrm{~kW}$ & $260-650 \mathrm{~kW}$ \\
\hline Solar Heating $\left(\mathrm{Q}_{\text {solar }}\right)$ & N/A & $460 \mathrm{~kW}$ \\
\hline Solar Collector Efficiency & N/A & $20-25 \%$ \\
\hline Water Temp through solar field & N/A & $343.15-363.15 \mathrm{~K}$ \\
\hline
\end{tabular}

Table-2, Parametric Results of combined double bed vapor adsorption System

\begin{tabular}{|c|c|c|c|c|c|}
\hline $\begin{array}{l}\text { Performance } \\
\text { Parameter }\end{array}$ & $\begin{array}{l}\text { Resultant } \\
\text { Values }\end{array}$ & $\begin{array}{l}\text { Performance } \\
\text { Parameter }\end{array}$ & $\begin{array}{l}\text { Resultant } \\
\text { Values }\end{array}$ & $\begin{array}{l}\text { Performance } \\
\text { Parameter }\end{array}$ & Resultant Values \\
\hline $\begin{array}{l}\text { Turbine work } \\
\text { output }\left(\mathrm{W}_{\text {HPT }} \&\right. \\
\left.\mathrm{W}_{\text {LPT }}\right)\end{array}$ & $\begin{array}{l}294.7 \& \\
1072 \mathrm{~kJ} / \mathrm{kg}\end{array}$ & $\begin{array}{l}\text { Condenser heat } \\
\text { exhaust (Qout) }\end{array}$ & $2133 \mathrm{~kJ} / \mathrm{kg}$ & $\begin{array}{l}\text { COP of combined } \\
\text { VAdRS } \\
\text { (COP }{ }_{\text {COMBINEDVADRS }} \text { ) }\end{array}$ & $\begin{array}{l}0.46 \text { to } 0.51(13-15 \% \\
\text { increment in overall } \\
\text { COP) }\end{array}$ \\
\hline $\begin{array}{l}\text { Pump Work } \\
\text { (W WUMP) }\end{array}$ & $16.23 \mathrm{~kJ} / \mathrm{kg}$ & $\begin{array}{l}\text { Plant Efficiency } \\
\left(\eta_{\mathrm{P}}\right)\end{array}$ & 0.388 & $\begin{array}{l}\text { Sp. Cooling Power } \\
\text { (SCP } \text { COMBINEDVADRs }^{\text {) }}\end{array}$ & $\begin{array}{l}70-90 \mathrm{~W} / \mathrm{kg}(10-16 \% \\
\text { increment in overall } \\
\mathrm{SCP})\end{array}$ \\
\hline $\begin{array}{l}\text { Boiler Heat } \\
\text { Generation } \\
\left(Q_{\text {IN }}\right)\end{array}$ & $3484 \mathrm{~kJ} / \mathrm{kg}$ & $\begin{array}{l}\text { Net Work } \\
\text { Output }\left(\mathrm{W}_{\mathrm{NET}}\right)\end{array}$ & $1350 \mathrm{~kJ} / \mathrm{kg}$ & $\begin{array}{l}\text { COP gain by Solar } \\
\text { energy (COP } \text { SOLAR })\end{array}$ & $\begin{array}{l}0.48-0.74 \text { (most } \\
\text { effective COP) }\end{array}$ \\
\hline
\end{tabular}




\section{IMAT3E'18 \\ International Meeting on Advanced Technologies in Energy and Electrical \\ Engineering}

\section{Conclusions}

The selection of a suitable working material depends on its process, application, heat source and the temperature level. The used material must have optimum thermodynamic properties at the lowest possible temperatures and pressures, and also satisfy the several criteria such as being economical, nontoxic, nonflammable, and environmentally friendly. All conventional refrigeration systems consume precious fuel or electricity to attain refrigeration. ORC and Adsorption systems are heat-operated units that need only heat in terms of un-covered heat from the energy intensive sectors, so they can utilize waste heat and generate multiple effects like heating, power and cooling. The major conclusion are drawn from both model analysis-

1. Cycle with solar coupling provides more heat for process. This is nearly two times that of the heat provided for process by the cycle without solar coupling, but the total work achieved in case of solar heating is less than that achieved without solar heating.

2. More power from the expanders is achieved when solar heating is not implemented. This is due to the heat generated by the solar heater is converted into process heat. Therefore, solar integration is recommended, for the purpose of obtaining more process heat, in summer and for the purpose of power generation in winter.

3. Solar integrated thermal circuit in combined power generation system enhances the cooling effect due to more heat addition through solar heating in R134a ORC system. R134a will attain superheating, and produce cooling effect.

4. The parametric table-6 concludes that the performance indicators (thermal efficiency, heating and cooling effect) of proposed system is increased by 30-40\% using solar system.

5. Parametric results, which are shown in table- 9 of double bed, vapor adsorption refrigeration system for heat recovery of Reheating-Rankine condenser, the overall COP and SCP enhanced by 10-16\% shown in figure- 6 .

6. Solar connected vapor adsorption bed gives more COP individually as compare to condenser connected vapor adsorption bed. The specific cooling power (SCP) of solar vapor adsorption bed is increasing but increasing of evaporation temperature will decrease the SCP of solar vapor adsorption bed due to conversion of solar gain into heating (Qheat-solar) by double rate. The variation of SCP between solar and without solar (bed-1 and bed-2) shown in figure-5.

7. The present combination of adsorbent-adsorbate material is suitable for low-grade heat recovery with solar thermal integration for continuous cooling effect generation and applicable for space cooling purpose. The used material R134a and methanol with activated carbon is most suitable pair under the category of eco-friendly material as per AHRAE guidelines of environmental safety protocol.All ecogriendly material have been shown in appendix tables.

8. The different materials have reviewed in present analysis. The two parameters are very important for environmental aspect, like GWP and ODP values. Minimum value of GWP \&OPD shows non-toxic and eco-friendly nature of material for power and cooling generation system. The proposed material also applicable for low-grade heat recovery purpose due to its low boiling and freezing temperature. 


\title{
Engineering
}

\author{
Abbreviations- \\ AC-Activated Carbon \\ ALT-Atmospheric Life Time \\ ASHRAE-American Society of Heating-Refrigeration and Air-Conditioning System \\ COP=Coefficient of Performance \\ CO2= Carbon Dioxide \\ ETC $=$ Evacuated Tube Collector \\ GEN=Generator \\ GWP=Global warming Potential \\ $\mathbf{H E}=$ Heat exchanger \\ HPT=High Pressure Turbine \\ LPT $=$ Low Pressure Turbine \\ ODP=Ozone depletion potential \\ ORC=Organic Rankine Cycle \\ $\mathbf{S C P}=$ Specific cooling power
}

\section{References}

[1]http://www1.eere.energy.gov/manufacturing/distributedenergy/ceacs.html

[2] https://www.epa.gov/ghgemissions/global-greenhouse-gas-emissions-data

[3] Vélez, F., Segovia, J., Martín, M.C., Antolín, G., Chejne, F. and Quijano, A., A technical, economical and market review of organic Rankine cycles for the conversion of low-grade heat for power generation. Renewable \& Sustainable Energy Reviews, vol. 16, pp. 4175-4189, 2012. pp. 188-195, 2012.

[4] Saleh, B., Koglbauer, G., Wendland, M. and Fischer, J., Working fluids low temperature organic Rankine cycles. Energy, Vol. 32, pp. 1210- 1221, 2007.

[5] Quolin, S., Declaye, S., Tchange, B.F. and Lemort, V., Thermo-Economic optimization of waste heat recovery organic Rankine cycles. Applied Thermal Engineering, vol. 31, pp. 2885-2893, 2011.

[6] Tchange, B.F., Papadakis, G., Lambrinos, G. and Frangoudakis, A.,Fluid selection for a lowtemperature solar organic Rankine cycle. Applied Thermal Engineering, vol. 29, pp. 2468-2476, 2009.

[7] Hung, T.C., Shal, T.Y. and Wang, S.K., A review of organic Rankine cycles (ORC`s) for the recovery of low-grade waste heat. Energy, vol. 22(7), pp. 661-667, 1997.

[8] Chen, H., Goswami, Y. and Stefanakos, E., A review of thermodynamic cycles and working fluids for the conversion of low-grade heat. Renewable \& Sustainable Energy Reviews, vol. 14, pp.3059-3067, 2010.

[9] U.S. Environmental Protection Agency. Class I Ozone Depleting Substances. [Online]. [date of reference March 11th of 2013] Available at: www.epa.gov/ozone/science/ods/classone.html.

[10] Roy, J.P., Mishra, M.K. and Misra, A., Parametric optimization and performance analysis of a waste heat recovery system using organic Rankine cycle. Energy, vol. 35, pp. 5049-5062, 2010.

[11] Manolakos, D., Papadakis, G., Mohamed, E., Kyritsis, S. and Bouzianas, K., Design of an autonomous low-temperature solar Rankine cycle system for reverse osmosis desalination. Desalination, vol. 183, pp. 73-80, 2005.

[12] Manolakos, D., Papadakis, G., Kyritsis, S. and Bouzianas, K., Experimental evaluation of an autonomous low-temperature solar Rankine cycle system for reverse osmosis desalination. Desalination, vol. 203, pp. 366-374, 2007. 
[13] Manolakos, D., Kosmadakis, G., Kyritsis, S. and Papadakis, G., On site experimental evaluation of a low-temperature solar organic Rankine cycle system for RO desalination. Solar Energy, vol. 83, pp. 646656, 2009.

[14] Manolakos, D., Kosmadakis, G., Kyritsis, S. and Papadakis, G., Identification of behaviour and evaluation of performance of small scale, low-temperature organic Rankine cycle system coupled with a RO desalination unit. Energy, vol. 34, pp. 767-774, 2009.

[15] Bruno, J.C., López-Villada, J., Letelier, E., Romera, S. and Coronas, A., Modelling and optimisation of solar organic Rankine cycle engines for reverse osmosis desalination. Applied Thermal Engineering, vol. 28, pp.2212-2226, 2008.

[16] Delgado-Torres, A. and García-Rodríguez, L., Analysis and optimization of the low-temperature solar organic Rankine cycle (ORC) Energy Conversion and Management, vol. 51, pp. 2846-2856, 2010.

[17] Thanche, B.F., Lambrinos, G., Frangoudakis, A. and Papadakis, G., Exergy analysis of microorganic Rankine power cycles for a small scale solar driven reverse osmosis desalination system. Applied Energy, vol. 87, pp. 1295-1306, 2010.

[18] Schuster, A. and Karl, J., Simulation of an innovative stand-alone solar desalination system using an organic Rankine cycle. Int. J. of Thermodynamics, vol. 10(4), pp. 155-163, 2007.

[19] Karellas, S., Terzis, K. and Manolakos, D., Investigation of an autonomous hybrid solar thermal ORC-PV RO desalination system. The Chalki island case. Renewable Energy, vol. 36, pp. 583-590, 2011. [20] Kosmadakis, G., Manolakos, D. and Papakakis, G., Parametric theoretical study of a two-stage solar organic Rankine cycle for RO desalination. Renewable Energy, 35, pp. 989-996, 2010.

[21] Franco, A. and Villani, M., Optimal design of binary cycle power plants for water-dominated, medium-temperature geothermal fields. Geothermics, vol. 38, pp. 379-391, 2009.

[22] Aneke, M., Agnew, B. and Underwood, C., Performance analysis of the Chena binary geothermal power plant. Applied Thermal Engineering, vol. 31, pp. 1825-1832, 2011.

[23] Astolfi, M., Xodo, L., Romano, M. and Macchi, E., Technical and economical analysis of a solargeothermal hybrid plant based on an organic Rankine cycle. Geothermics, vol. 40, pp. 58-68, 2011.

[24] Wang, L.W., R.Z. Wang, R.G. Oliveira. 2009. "A review on adsorption working pairs for refrigeration." Renewable and Sustainable Energy Reviews, 13(3):518 - 534.

[25] Wang, K., O. Abdelaziz, P. Kisari, E.A. Vineyard. 2011. "State-of-the-Art Review on Crystallization Control Technologies for Water/LiBr Absorption Heat Pumps." International Journal of Refrigeration 34(6):1325 - 1337.I

[26] http://www.ormat.com

[27] O. Badr, S.D Probert and P.W. O'Callaghan, Selecting a working fluid for a Rankine-cycle engine, Applied Energy 21 (1985) 1-42.

[28] M.J. Lee, D.L. Tien, C.T. Shao, Thermophysical capability of ozone-safe working fluids for anorganicrankine cycle system, Heat Recovery Systems \& CHP 13 (1993) 409-418.

[29] Kyoto Protocol to the United Nations Framework Convention on Climate Change, United Nations, 1998 
IMAT3E'18

International Meeting on Advanced Technologies in Energy and Electrical

Engineering

Appendix-

Table-A Energy recovery and its sources [26]

\begin{tabular}{|c|c|c|c|}
\hline Heat Categories & Heat Sources & Temperature in ${ }^{0} \mathrm{C}$ & Suggested recovery technology \\
\hline \multirow{5}{*}{$\begin{array}{l}\text { High Grade } \\
\left(>650^{\circ} \mathrm{C}\right)\end{array}$} & Solid waste & $650-1000$ & Air preheating \\
\hline & Nickel refining furnace & $1370-1650$ & Steam generation for heating \\
\hline & Copper reverberator furnace & $760-815$ & Thermoelectric and thermal PV \\
\hline & Glass melting furnace & $1000-1550$ & Heat exchanger for preheating \\
\hline & Hydrogen plant & $650-1000$ & Thermal PV \\
\hline \multirow{5}{*}{$\begin{array}{l}\text { Medium Grade } \\
\left(230-650^{\circ} \mathrm{C}\right)\end{array}$} & Steam boiler exhaust & $230-480$ & Steam rankine cycle \\
\hline & Gas turbine exhaust & $370-540$ & Organic rankine cycle \\
\hline & Drying and baking ovens & $230-600$ & Thermal PV \\
\hline & Catalytic crackers & $425-650$ & Thermal PV \\
\hline & $\begin{array}{c}\text { Reciprocating engine } \\
\text { exhaust }\end{array}$ & $315-600$ & Thermoelectric \\
\hline \multirow{4}{*}{$\begin{array}{l}\text { Low Grade } \\
\left(>230^{0} \mathrm{C}\right)\end{array}$} & $\begin{array}{l}\text { Welding and injection } \\
\text { molding }\end{array}$ & $32-88$ & Kalina cycle \\
\hline & $\begin{array}{l}\text { Hot processed liquids and } \\
\text { solids }\end{array}$ & $32-233$ & Organic rankine cycle \\
\hline & $\begin{array}{c}\text { Drying, Baking and Curing } \\
\text { ovens }\end{array}$ & $93-230$ & $\begin{array}{l}\text { Absorption and adsorption } \\
\text { cooling }\end{array}$ \\
\hline & Bearing & $32-88$ & Piezoelectric \\
\hline
\end{tabular}

Table-B: Summary of Commercialized Working fluids [27-29]

\begin{tabular}{|c|c|c|c|c|c|c|c|c|c|}
\hline \multirow[b]{2}{*}{$\begin{array}{l}\text { S. } \\
\text { No }\end{array}$} & \multirow{2}{*}{$\begin{array}{l}\text { Working } \\
\text { Fluids }\end{array}$} & \multicolumn{4}{|c|}{ Physical Data } & \multirow{2}{*}{$\begin{array}{l}\begin{array}{l}\text { Safety } \\
\text { Data }\end{array} \\
\text { ASHRA } \\
\text { E } \\
\text { Group }\end{array}$} & \multicolumn{3}{|c|}{ Environmental Data } \\
\hline & & $\begin{array}{l}\text { Molecul } \\
\text { ar Mass } \\
(\mathrm{Kg} / \mathrm{K} \\
\mathrm{mol})\end{array}$ & $\begin{array}{l}\text { Normal } \\
\text { Boiling } \\
\text { Point } \\
\text { Temp } \\
\left(\mathbf{T}_{\text {bp }}\right) \text { in }{ }^{0} \mathrm{C}\end{array}$ & $\begin{array}{l}\text { Critica } \\
\text { I Temp } \\
\left(\mathbf{T}_{\text {criti }}\right) \\
\text { in }{ }^{0} \mathrm{C}\end{array}$ & $\begin{array}{l}\text { Critic } \\
\text { al } \\
\text { Pressu } \\
\text { re } \\
\left(P_{\text {criti }}\right) \\
\text { in } \\
\text { MPa } \\
\end{array}$ & & $\begin{array}{l}\text { Atmosph } \\
\text { eric Life } \\
\text { Time } \\
\text { (ALT) in } \\
\text { years }\end{array}$ & $\begin{array}{l}\text { Ozone } \\
\text { Depletion } \\
\text { potential } \\
\text { (ODP) }\end{array}$ & $\begin{array}{l}\text { Global } \\
\text { Warming } \\
\text { Potential } \\
\text { (GWP) of } 100 \\
\text { years }\end{array}$ \\
\hline 1 & RC118 & 200.03 & -6.0 & 115.2 & \begin{tabular}{|l}
2.778 \\
\end{tabular} & A1 & 3200 & 0 & 10225 \\
\hline 2 & R600a & 58.12 & -11.7 & 135 & \begin{tabular}{|l|}
3.647 \\
\end{tabular} & A3 & 0.017 & 0 & 20 \\
\hline 3 & R114 & 170.92 & 3.6 & 145.7 & \begin{tabular}{|l|}
3.289 \\
\end{tabular} & A1 & 300 & 1.00 & 10040 \\
\hline 4 & R600 & 58.12 & -0.5 & 152 & 3.796 & A3 & 0.018 & 0 & 20 \\
\hline 5 & R601 & 72.15 & 36.1 & 196.5 & 3.364 & NA & 0.01 & 0 & 20 \\
\hline 6 & R113 & 187.38 & 47.6 & 214.1 & 3.439 & A1 & 85 & 1.000 & 6130 \\
\hline 7 & $\begin{array}{l}\text { Cyclohex } \\
\text { ane }\end{array}$ & 84.16 & 80.7 & 280.5 & 4.075 & A3 & NA & NA & NA \\
\hline 8 & R290 & 44.10 & -42.1 & 96.68 & 4.247 & A3 & 0.041 & 0 & $\sim 20$ \\
\hline 9 & $\mathrm{R} 407 \mathrm{C}$ & 86.20 & -43.6 & 86.79 & $\begin{array}{l}4.597 \\
\end{array}$ & A1 & NA & 0 & 1800 \\
\hline 10 & R32 & 52.02 & -51.7 & 78.11 & \begin{tabular}{|l|}
5.784 \\
\end{tabular} & A2 & 4.9 & 0 & 675 \\
\hline 11 & R500 & 99.30 & -33.0 & 105.5 & 4.455 & A1 & NA & 0.738 & 8100 \\
\hline 12 & R152a & 66.05 & -24.0 & 113.3 & \begin{tabular}{|l|}
4.520 \\
\end{tabular} & A2 & 1.40 & 0 & 124 \\
\hline 13 & $\begin{array}{l}\text { R717 } \\
\text { (Ammon } \\
\text { ia) }\end{array}$ & 17.03 & -33.3 & 132.3 & 11.333 & $\mathrm{~B} 2$ & 0.1 & 0 & $<1$ \\
\hline 14 & Ethanol & 46.07 & 78.4 & 240.8 & \begin{tabular}{|l|l|}
6.148 \\
\end{tabular} & NA & NA & NA & NA \\
\hline
\end{tabular}


IMAT3E'18

International Meeting on Advanced Technologies in Energy and Electrical

\section{Engineering}

\begin{tabular}{|l|l|l|l|l|l|l|l|l|l|}
\hline 15 & Methanol & 32.04 & 64.4 & 240.2 & 8.104 & NA & NA & NA & NA \\
\hline 16 & $\begin{array}{l}\text { R718 } \\
\text { (Water) }\end{array}$ & 10.2 & 100 & 374 & 22.064 & A1 & NA & 0 & $<1$ \\
\hline 17 & R134a & 102.03 & -26.1 & 101 & 4.059 & A1 & 14.0 & 0 & 1430 \\
\hline 18 & R12 & 120.91 & -29.8 & 112 & 4.114 & A1 & 100 & 1.000 & 10890 \\
\hline 19 & R123 & 152.93 & 27.8 & 183.7 & 3.668 & B1 & 1.3 & 0.02 & 77 \\
\hline 20 & R141b & 116.95 & 32.0 & 204.2 & 4.249 & NA & 9.3 & 0.120 & 725 \\
\hline 21 & R245fa & 134.05 & 15.3 & 154.1 & 3.64 & B1 & 8.8 & 0 & 820 \\
\hline 22 & R236fa & 152.0 & -1.5 & 124.0 & 3.20 & - & 209 & 0 & 6300 \\
\hline 23 & R227ea & 170.0 & -17.5 & 102.0 & 2.95 & - & 36.5 & 0 & 2900 \\
\hline 24 & R1234yf & 114.02 & -29.45 & 94.7 & 3.382 & A1 & NA & $\sim 0$ & 4 \\
\hline
\end{tabular}

Table-C- Energy Recovery Materials for Adsorption Refrigeration Techniques of Heat Recovery [24]

\begin{tabular}{|c|c|c|c|}
\hline Material & Heat Source & $\begin{array}{l}\text { Performance } \\
\text { (COP) }\end{array}$ & Application \\
\hline \multirow{4}{*}{ AC-Methanol } & $20 \mathrm{MJ} / \mathrm{m} 2$ per Day & 0.12 & \multirow{8}{*}{ Ice Making } \\
\hline & $\begin{array}{l}18 \text { to } 19.2 \mathrm{MJ} / \mathrm{m} 2 \text { per } \\
\text { Day }\end{array}$ & 0.12 to 0.14 & \\
\hline & 17 to $20 \mathrm{MJ} / \mathrm{m} 2$ per Day & 0.13 to 0.15 & \\
\hline & $<120$ degree $\mathrm{C}$ & 0.18 & \\
\hline AC-NH3 & 105 degree $\mathrm{C}$ & 0.10 & \\
\hline Silica Gel-Water & $15.4 \mathrm{MJ} / \mathrm{m} 2$ per Day & 0.16 & \\
\hline $\begin{array}{l}\text { AC-Blanked steel- } \\
\text { Methanol }\end{array}$ & $20 \mathrm{MJ} / \mathrm{m} 2$ per Day & 0.18 & \\
\hline $\mathrm{AC}+\mathrm{CaCl} 2-\mathrm{NH} 3$ & 115 degree $\mathrm{C}$ & 0.39 & \\
\hline \multirow{5}{*}{ Silica Gel-Water } & 55 degree $\mathrm{C}$ & 0.36 & \multirow{5}{*}{ Chilled Water } \\
\hline & 65 degree $\mathrm{C}$ & 0.28 & \\
\hline & 75-90 MJ/m2 per Day & 0.35 to 0.60 & \\
\hline & 80 to95 $\mathrm{MJ} / \mathrm{m} 2$ per Day & 0.35 to 0.60 & \\
\hline & $80 \mathrm{MJ} / \mathrm{m} 2$ per Day & 0.33 to 0.50 & \\
\hline \multirow[b]{2}{*}{ AC-NH3 } & 232 degree $\mathrm{C}$ & 0.42 to 1.19 & \multirow{6}{*}{ Air Conditioning } \\
\hline & 100 degreeC & 0.20 & \\
\hline \multirow{4}{*}{ Zeolite-Water } & 204 degree $\mathrm{C}$ & 0.60 to 1.60 & \\
\hline & 230 degreeC & 0.41 & \\
\hline & 310 degreeC & 0.38 & \\
\hline & 230 to 300 degreeC & 0.20 to 0.21 & \\
\hline
\end{tabular}

